\title{
Veterinary science in the nascent state: the animal hospital in Vilnius, 1834-1842*)
}

\author{
ANITA MAGOWSKA \\ Department of History of Medical Sciences, Poznan University of Medical Sciences, \\ Przybyszewskiego Street 37A, 60-346 Poznan, Poland
}

Magowska A.

Veterinary science in the nascent state: the animal hospital in Vilnius, 1834-1842

Summary

This article investigates early trends in veterinary research using a comparative analysis of historical records concerning a model early-19th-century animal hospital. Such a hospital was organized at the Medical and Surgical Academy in Vilnius in 1834-1842 to provide clinical teaching for vets and control animal plagues and was assumed to be a model one because its structure and activity were patterned on the best veterinary hospitals at that time which existed in Lyon, Alfort and Vienna.

It has been shown that the characteristic features of veterinary medicine in the period under consideration included: conducting clinical observations and performing autopsies to clarify the pathogeneses of animal diseases; studying epizootics; anthropomorphizing sick animals, which involved borrowing knowledge from medical theories and applying fashionable therapies used on humans to animals; as well as providing practical education to vets to make them versatile and independent. Horses and dogs were the most numerous groups of patients treated at the Vilnius animal hospital.

Keywords: history of veterinary medicine; animal hospital; epizootics

For centuries, victories in wars and the fates of nations have been determined more by horses than commanders; moreover, indirectly by blacksmiths who have been caring for steeds' health using methods borrowed from barbers, such as bloodletting and administering laxatives (9). Recognizing the military and economic significance of horses, Claude Bourgelot (1712-1779) founded the first veterinary school in Lyon in 1862. It became an example for successive schools established in Alfort, Vienna, and other cities of Western Europe (11). In Eastern Europe, the first veterinary school was opened at Vilnius University in 1823. In mid-1832, however, both the school and the university were closed by the tsarist authorities, who thus wanted to punish the Poles and Lithuanians for the recent anti-Russian uprising. Their substitute became the Medical and Surgical Academy which began its operation in Vilnius in August 1832. Teaching courses and research were conducted in clinics, departments and auxiliary units of the Medical Faculty of the Uni-

*) This study was partly supported by the Polish National Programme for the Development of Humanities. versity, including those belonging to the veterinary school. The Academy trained veterinarians for the Russian army and administration until 1842, when it was finally closed down by decree of the tsar (4). After it closed, the Vilnius veterinary school influenced the development of veterinary medicine in Eastern Europe through its graduates. The heads of veterinary schools, such as Edward Ostrowski (1816-1859) in Warsaw and Kharkov and Napoleon Halicki (1818-1881) in Kharkov, enjoyed the greatest fame (11).

The historical works on the animal hospital that was functioning as part of the veterinary school at the Medical and Surgical Academy in Vilnius in 1834-1842 were analyzed and compared with early treatises and doctoral dissertations on veterinary medicine to identify the features of veterinary science in the nascent state.

In 1804 Ludwig Bojanus (1776-1827), a graduate of medical studies in Jena and Vienna and the best veterinary schools in Europe, arrived from Darmstadt in Germany to Vilnius in the Russian partition of the former Polish-Lithuanian Commonwealth to organize a veterinary school. However, a lack of appropriately 
qualified teaching staff and sufficient funds were obstacles impossible to overcome (2). Only a few years after the Franco-Russian War of 1812, Bojanus began lectures on comparative anatomy, epidemiology and other veterinary sciences to students of medicine. The three students who achieved the best exam grades, Adam Ferdynand Adamowicz (1802-1881), Karol Muyschel (1799-1843) and Fortunat Jurewicz (1801-1826), were sent to veterinary schools in France, Germany and Austria. They returned in 1823 when Bojanus managed to start a veterinary school with a four-year teaching programme. Soon poor health forced him to leave Vilnius forever and to hand the school management over to F. A. Adamowicz, who headed the school until the University was closed in 1832 (7).

After establishing the Medical and Surgical Academy, the veterinary school was reactivated, but only with a three-year curriculum. The animal hospital was reopened on 26 March 1834, i.e., later than the school (4). As in the days of the university, it was located in a specially built stable consisting of twenty-three stalls for sick animals, of which twelve were designated for horses ( six of them for the Clinic of Veterinary Therapy and the other six for the Clinic of Veterinary Surgery), three for goats, four for sheep and four for dogs (9). The provision of advice, medicines and operations on animals was free but their owners had to supply the required amount of feed and bedding (4). The standard daily fodder was fifteen pounds of hay and three gallons of oats for a horse, twelve pounds of hay for a cow or an ox and five pounds of hay for a sheep. City dwellers were required to provide hay, oats and straw for three days, and villagers for eight days. If a disease lasted longer, and the owner of the animal did not supply the feed, the animal was treated at the expense of the government and sold after the treatment (8).

The daily activities of the animal hospital were managed by a student on duty. When a sick animal was brought in, he entrusted its care to one of his colleagues who was obliged to examine it, treat it on his own and mix all necessary medicines at the veterinary pharmacy. He would administer these at fixed hours in the presence of the student on duty and watch the beast at different times of the day, recording its condition in the history of the disease. In the case of sudden problems, he would seek help from a pharmacist, a prosector, a so-called educated blacksmith or a lecturer. He would also inform a professor about any disturbing changes in the appearance or the behaviour of the animal. If the animal died, its body was dissected. In such a manner particular animal diseases were better recognized (8).

Bojanus left for Darmstadt in 1824, but before doing so, he published a book entitled Conspectus morborum inter animalia observatorum nosologicum in Vilnius. In his book, he gave the names of animal diseases and their main symptoms, starting with the most important old and new medical theories including those by Hippocrates, Celsus, Fracastoro, John Hunter and

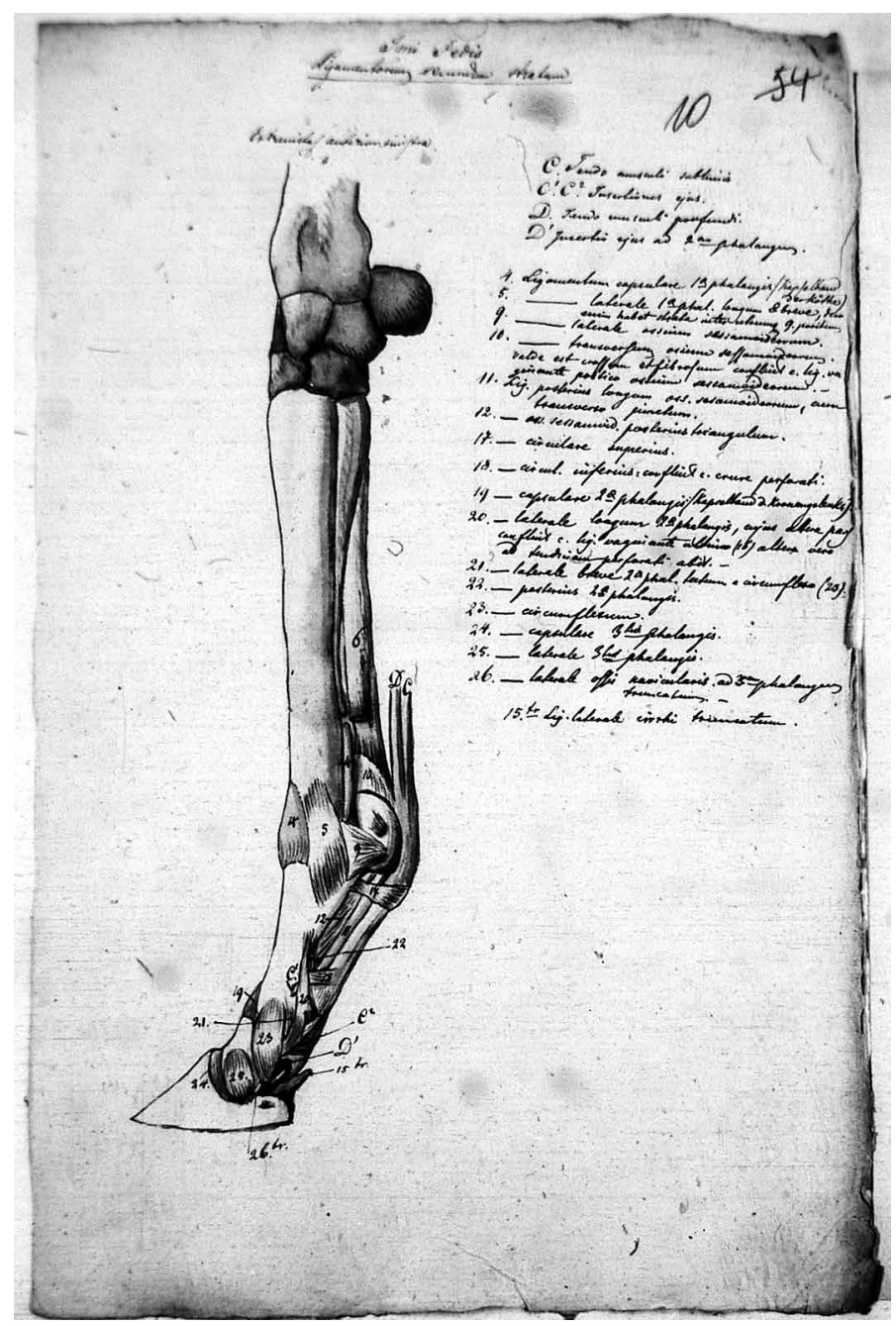

Fig. 1. A drawing made by Ludwig Bojanus for lectures on anatomy (National Historical Archive of Lithuania, F 1135$-5-16$, p. 10, photo by the author)

William Cullen. Apparently he considered his work to be incomplete because there were blank pages at the end of each chapter on which readers could note down their own observations (5). This work is almost identical to Adam Ferdynand Adamowicz's Ph.D. dissertation entitled Dissertatio inauguralis medico-veterinaria morborum inter animalia domestica observatorum indicem singulorumque constantissima signa exhibens, adnexa synonimia germanica, gallica, rossica et polonica (1). On 31 May 1824 it was accepted for printing by - and this needs to be emphasized - Bojanus, who was a university censor at that time. After Conspectus morborum... was printed, Bojanus apparently decided to leave Vilnius and gave this book to the then twenty-two-year-old Adamowicz to help him obtain his Ph.D. degree and take over the post of the head of the veterinary school (3).

Similar to Conspectus morborum..., Adamowicz's dissertation was a lexicon of veterinary terminology. Adamowicz described the most important symptoms of animal diseases. Following Bojanus, he combined the medical theories about humans that were popular in English- and German-speaking countries with observations about sick animals. He included the names 
of diseases in different languages, including Russian and Polish, which made it easier to communicate with servants bringing sick animals to the veterinary hospital. Following the fourfold division of human diseases introduced by Hippocrates, he divided animal diseases into four classes: fever (Pyrexiae vel Febres), somatic disorders not necessarily associated with fever (Morbi singulorum corporis systematum absque necessaria pyrexia), states of cachexia (Cachexiae) and local diseases (Morbi locales). He singled out specific categories within each class, also relying on the classification of human diseases of that time. For example, he classified melancholy and lumbago as animal somatic diseases without fever (1).

Thanks to Bojanus, Adamowicz learned about the classification of animal diseases adopted in Western Europe, but he did not manage to gain knowledge about their treatment. He therefore took to Ferdinand Spitznagel's medical lectures given in Vilnius and on this basis developed the practical principles of animal treatment. The consequence of classifying symptoms by analogy was a therapy by analogy, as animals were usually treated in the same way as people in the clinical hospital directed by Adamowicz. Thus, diet played a fundamental role in the therapy. Abundant food was administered to animals suffering from long-term diseases accompanied by weakness, abscesses, rashes and pain. Food rations were reduced after surgery and in inflammation, and feeding was even stopped in ruminants. The activities that had specific medicinal value were also: movement and rest, bloodletting, dragging (where a cord was introduced under the skin through special cuts to cause inflammation and abscesses), cauterization with a hot iron, cutting the skin and trepanation of the skull (8).

Adamowicz preferred liquid medicines. These were prepared using ordinary water (Aqua communis) as the base with the addition of a variety of salts, and administered as a cold - which had therapeutic relevance - or a heated beverage, or used for bathing diseased animals. Adamowicz recommended that animals should be treated using compounds of lead, copper, antimony and sulphur (including Glauber's salt, i.e., magnesium sulphate, which was a popular laxative used in human therapies), and potassium nitrate, then valued as a remedy for diseases of the nervous system. Animals were sometimes treated with infusions of arnica flowers (Arnica montana) and other plant materials for human use (1). Treating animals with juniper berries, sweet flag rhizomes and other very mild herbs was described by Bojanus in his book $O$ wazniejszych zarazach bydta rogatego i koni [The Most Important Diseases of Horned Cattle and Horses], published in 1810 in Vilnius and Warsaw (6). Adamowicz, however, went even further and introduced some potent plant materials from Spitznagel's lectures, such as: the narcotic plant and root of deadly nightshade (Atropa belladonna), administered to animals as an antitussive; foxglove

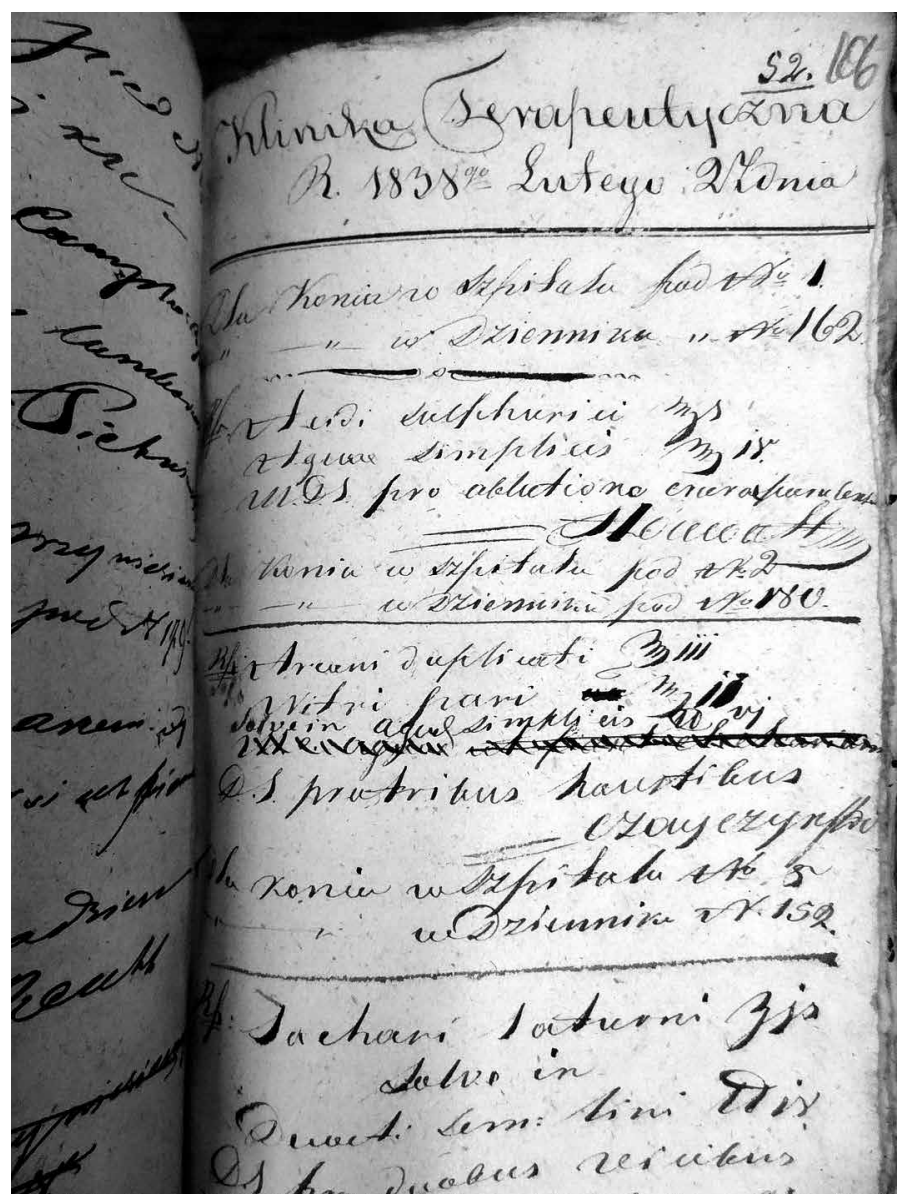

Fig. 2. A formulary used in the animal hospital, dated 1838 (Vilnius University Library, F 26-3720, p. 87, photo by the author)

leaves (Digitalis purpurea), used as a diuretic; as well as turpentine and tobacco, which were a veritable panacea used to exterminate insects in the nostrils of animals, treat generalized oedema, and wash pustules. Some medications were administered to animals intravenously by incising the jugular vein to introduce a groove probe and insert the tube of a sprinkler into the neck (8).

In the light of the aforementioned book $O$ wazniejszych zarazach bydła rogatego $i$ koni, Bojanus can be considered a pioneer of the modern fight against epizootics. He took issue with the view that these diseases are caused by bad air or malnutrition, and showed that they are spread through infection from diseased animals or their unaware carers. He recommended that people who had contact with sick animals clean themselves and incense the rooms with sulphur. In his opinion, the most dangerous epizootic diseases were the cow pox (lues bovilla) and the contagious bovine pleuropneumonia, which often occurred at the time, leading to the extinction of almost entire herds. He stressed that the only way to fight the plagues was to slaughter whole herds. It was possible, however, to prevent them by quarantining newly purchased animals and vaccinating them by cutting the skin on their hind legs and dragging through it a cord immersed in secretions from the eyes or nostrils of sick animals (6). 
Tab. 1. Statistics concerning the treatment of horses and dogs at the veterinary hospital in Vilnius from 26 March 1834 until the end of the academic year 1839/1840 (8)

\begin{tabular}{|c|c|c|c|c|c|c|}
\hline \multirow{2}{*}{ Period } & \multicolumn{3}{|c|}{ The number of admitted animals } & \multicolumn{3}{|c|}{ The number of deceased animals } \\
\hline & Total & Including ... horses & Including ... dogs & Total & Including ... horses & Including ... dogs \\
\hline From 28 March 1834 until 28 June 1834 & 96 & 74 & 17 & 13 & 8 & 3 \\
\hline Academic year 1834/1835 & 228 & 156 & 50 & 39 & 20 & 7 \\
\hline Academic year 1835/1836 & 318 & 193 & 99 & 36 & 11 & 20 \\
\hline Academic year 1836/1837 & 422 & 250 & 131 & 43 & 17 & 17 \\
\hline Academic year 1837/1838 & 439 & 238 & 139 & 62 & 18 & 32 \\
\hline Academic year 1838/1839 & 437 & 254 & 143 & 75 & 29 & 31 \\
\hline Academic year 1839/1840 & 424 & 237 & 149 & 55 & 25 & 20 \\
\hline Total & 2,364 & 1,402 & 728 & 320 & 128 & 130 \\
\hline
\end{tabular}

Due to a lack of veterinary services in Eastern Europe, Bojanus' views were not well known and did not affect the protection of farm animals in the Vilnius region. His successors, Adamowicz and Muyschel, repeatedly affirmed the violation of reasonable rules of conduct on infected animals. They were not slaughtered, and when they died, they were skinned and their meat was eaten. When the scholars were called by estate owners to help control epidemics, they gathered data on the size of herds of cattle, horses, goats, pigs and sheep, the number of dead animals and those who recovered, as well as the number of people who were infected and died of zoonoses. For instance, in Kaunas and its surroundings in 1834, 40-70\% of farm animals were infected with anthrax (which was then called carbuncle), and 3-20\% died. Twenty-eight people were infected by skinning dead animals and eating their flesh, one of them died. Zoonotic diseases were so easily spread because numerous horses, cattle and pigs were kept in cities. Sticking with the example of Kaunas, there were 280 horses, 390 cows and oxen, 150 pigs, 30 sheep and 18 goats in this city alone (8).

Epizootic diseases were recorded in the journal of the animal hospital at the end of each academic year. Hence, it is known that diseases that prevailed in the Vilnius region in the spring of 1834 included pharyngitis in cattle and dogs, bloody urine in cattle, as well as contagious bovine pleuropneumonia and anthrax in different species of animals. By comparison, sheep pox and rabies in dogs occurred in the Vilnius region in the academic year 1836/1837, and later moved to horned cattle and pigs, causing the death of many animals. In the next academic year, foot-and-mouth disease of cattle was brought to the vicinity of Vilnius with stocks purchased in Russia, and sheep pox was observed in the remote Minsk province. In 1838/1839, so many horses suffered from laminitis that it was considered to be an infectious disease. In addition, cows often miscarried as they were fed rotten straw from roofs due to crop failure. There were also numerous cases of anthrax, pneumonic plague and liver flukes (8).

The most common patients of the veterinary hospital in Vilnius were horses: there were 1847 of them, of which 159 (about 9\%) died (9). They were brought there for various reasons. For example, in the academic year $1834 / 1835$, one of the horses was diagnosed with polyuria (which was then called diabetes) and treated with camphor and lime water (8). Horses were also treated in the surgical clinic. Only in $1841 / 1842$ that 395 horses were brought for treatment. Their enlarged lymph glands were enucleated due to glanders, ulcers were cauterised or incised, and their tails were cut off (9). These horses belonged to the professors of the Medical and Surgical Academy, nobles, clergy, officers and civil servants of Russia (8).

Dogs were the second most numerous group of animals treated at the veterinary hospital (see Table 1). For example, in the academic year 1834/1835, 50 dogs were treated there, most of them were hunting dogs: 13 pointers - one of which was diagnosed with epilepsy, 10 spitzes, 5 poodles - used for hunting birds in the nineteenth century, 2 Danish greyhounds, 2 scent hounds, a fox terrier and an English pointer. Little dogs kept for companionship and adornment, such as the Bolognese, were increasingly brought to the hospital (8).

Dogs suffered from rheumatism, lichen, inflammation of the eyes, and were sometimes victims of unintentional injuries. They were occasionally brought in to have the tail and ears cut. There were also such unusual patients as nightingales, canary birds of the Chinese and English race, and a bear who died after several weeks of treatment in the veterinary hospital. The animal was subjected to an autopsy, which showed that it had a large amount of water in the chest cavity. A separate and less numerous category of sick animals included cows, oxen, sheep, goats and pigs. The worst results were obtained in the treatment of sheep which suffered from sheep pox despite vaccination. From time to time sick hens were brought to the hospital and healed (8).

The animal hospital became the driving force behind the development of veterinary medicine in Vilnius. The strength of the hospital was that clinical observations were conducted and recorded in the history of disease, and were profiled for veterinary surveillance over 
a large territory. The veterinary school at the Medical and Surgical Academy in Vilnius provided education to meet the needs of the region; i.e., treatment of horses and cattle. The documentation of the animal hospital shows that pigs and sheep were rarely bred in the Vilnius region. Researchers affiliated with the hospital studied epizootic diseases, their pathogeneses and infectivity for humans and various animal species. Owners of sick animals were willing to bring them there, guided by their material value, utility or - more and more often - sentiments.

The veterinary medicine in its nascent state was characterized mainly by the anthropomorphization of sick animals; i.e., classifying and interpreting their health problems from the perspective of knowledge about human diseases. Its other features were: efforts in the control of epizootics, clinical teaching as the gold standard of education for vets, and therapies based on diets, baths and mineral waters by analogy with the methods used in humans. It is significant that more and more small animals kept for entertainment were treated in the animal hospital, including a nightingale and a canary.

\section{References}

1. Adamowicz A. F.: Dissertatio inauguralis medico-veterinaria morborum inter animalia domestica observatorum indicem singulorumque constantissima signa exhibens, adnexa synonimia germanica, gallica, rossica et polonica. Typis B. Neumann, Vilnius 1824

2. Adamowicz A. F.: Ludwik Bojanus. Wizerunki i Roztrząsania Naukowe 1836, 11, 50-93.

3. Beauvois D.: Wilno - polska stolica kulturalna zaboru rosyjskiego 1803-1832. Wydawnictwo Uniwersytetu Wrocławskiego, Wrocław 2012.

4. Bieliński J.: Stan nauk lekarskich za czasów Akademii Medyko-Chirurgicznej wileńskiej bibliograficznie przedstawiony. Wydawnictwo Towarzystwa Lekarskiego Warszawskiego, Warszawa 1888.

5. Bojanus L.: Conspectus morborum inter animalia observatorum nosologicum. Typis J. Zawadzki, Vilnius 1824.

6. Bojanus L. H.: O ważniejszych zarazach bydła rogatego i koni. Drukarnia J. Zawadzkiego, Wilno - Warszawa 1810.

7. Fedorowicz Z.: Ludwik Henryk Bojanus. Ossolineum, Wrocław 1958.

8. Magowska A.: Kształtowanie się medycyny weterynaryjnej w Wilnie w świetle archiwaliów z pierwszej połowy XIX w. Acta Med. Pol. 2016, 7:2, 3-16.

9. Perenc A.: Historia lecznictwa dla zwierząt w Polsce. Toruń 1836.

10. Rotkiewicz T.: Piśmiennictwo weterynaryjne, [in:] Rotkiewicz T. (ed): Historia weterynarii i deontologia. Wydawnictwo Uniwersytetu WarmińskoMazurskiego w Olsztynie, Olsztyn 2006, 79-99.

11. Rotkiewicz T., Tarczyński S.: Szkolnictwo weterynaryjne, [in:] Rotkiewicz T. (ed): Historia weterynarii i deontologia, Wydawnictwo Uniwersytetu Warmińsko-Mazurskiego w Olsztynie, Olsztyn 2006, 100-175.

Corresponding author: Prof. Anita Magowska PhD, Przybyszewskiego 37A, 60-356 Poznan, e-mail: vesalius@ump.edu.pl 